\title{
Can prosthesis design of total knee arthroplasty affect balance?
}

\author{
Total diz artroplastisinin protez tasarımı dengeyi etkileyebilir mi?
}

\author{
Mehmet İsyar, MD., ${ }^{1}$ İlknur Saral, MD., ${ }^{2}$ Olcay Güler, MD., ${ }^{1}$ Engin Çakar, MD., ${ }^{2}$ Mahir Mahiroğulları, MD. ${ }^{1}$ \\ 1'Department of Orthopedics and Traumatology, Medical Faculty of Medipol University, İstanbul, Turkey \\ ${ }^{2}$ Department of Physical Medicine and Rehabilitation, Medical Faculty of Medipol University, İstanbul, Turkey
}

\section{ABSTRACT}

Objectives: In this study, we aimed to investigate whether posterior cruciate ligament (PCL) retaining or substituting in total knee arthroplasty affect the balance.

Patients and methods: Between March 2010 and April 2014, a total of 41 patients who underwent total knee arthroplasty in our clinic were included in the study. A PCL-substitution prosthesis was used in 21 patients (group 1) and a PCL-retaining prosthesis was used in 20 patients (group 2). Balance and fall risk were evaluated using a balance assessment device. The patients were examined by the Berg Functional Balance Scale.

Results: The mean follow-up was $25.6 \pm 9.7$ months. There was no statistically significant difference in static or dynamic overall stability, mediolateral stability or fall risk between the two types of prostheses. A significant difference in the dynamic anteroposterior stability index scores was observed between the groups.

Conclusion: Our study results show that PCL-substitution prosthesis affects the balance positively in total knee arthroplasty. Therefore, PCL-substitution prosthesis design should be considered for patients who have risk factors for balance disorder, in particular.

Keywords: Fall risk; imbalance; posterior cruciate ligament retaining; posterior cruciate ligament substitution; total knee arthroplasty.

\section{$O ̈ Z$}

Amaç: $\mathrm{Bu}$ çalışmada total diz artroplastisinde arka çapraz bağın (AÇB) kesilmesi ya da korunmasının dengeyi etkileyip etkilemediği araştırıldı.

Hastalar ve yöntemler: Bu çalışmaya Mart 2010 - Nisan 2014 tarihleri arasında kliniğimizde total diz artroplastisi uygulanan 41 hasta dahil edildi. Bunların 21'inde (grup 1) AÇB kesen protez, 20'sinde (grup 2) ise AÇB koruyan protez kullanıldı. Denge ve düşme riski, denge sistem cihazı yardımıyla değerlendirildi. Hastalar Berg Fonksiyonel Denge Ölçeği ile analiz edildi.

Bulgular: Ortalama takip süresi $25.6 \pm 9.7$ ay idi. İki tip protez arasında statik veya dinamik genel stabilite, mediolateral stabilite veya düşme riski açısından istatistiksel olarak anlamlı bir fark yoktu. Gruplar arasında anteroposterior stabilite indeks skorları açısından anlamlı bir fark bulundu.

Sonuç: Çalışma sonuçlarımız, total diz artroplastisinde AÇB kesen protezin dengeyi olumlu yönde etkilediğini göstermektedir. $\mathrm{Bu}$ nedenle, özellikle denge bozukluğu risk faktörü taşıyan hastalarda, AÇB kesen protez tasarımı kullanılmalıdır.

Anahtar sözcükler: Düşme riski; dengesizlik; arka çapraz bağı kesen; arka çapraz bağı koruyan; total diz artroplastisi.
Even in developed countries, falls hospitalize approximately $6 \%$ of the elderly, and in half of the cases, recurrent falls are observed. ${ }^{[1-4]}$ Neurological, musculoskeletal, and cardiovascular problems, and previous surgical procedures increase the risks of poor balance and falls in elderly, particularly. ${ }^{[5]}$

It is well-established that posterior cruciate ligament (PCL)-retaining and PCL-substitution prostheses are placed during total knee arthroplasty (TKA) in elderly with advanced gonarthrosis. ${ }^{[6]}$ However, it remains unclear whether the implant design affects the balance and fall risks. One of the most controversial issues in TKA is whether to substitute or retain the PCL and it has been suggested that the choice is associated with risks of poor balance and falls postoperatively. In the present study, we aimed to investigate whether PCL-substitution or

- Received: March 12, 2015 Accepted: April 25, 2015

- Correspondence: Mehmet İsyar, MD. Medipol Üniversitesi Tıp Fakültesi Ortopedi ve Travmatoloji Anabilim Dalı, 34214 Bağcılar, İstanbul, Turkey. Tel: +90 533 - 7227971 Fax: +90 212 - 4607070 e-mail: misyar2003@yahoo.com 
PCL-retaining prostheses affect the balance in TKA. We evaluated such risks both in the laboratory and clinical setting with balance assessment systems.

\section{PATIENTS AND METHODS}

This study was performed in balance laboratory of our university and was approved by institutional local ethics committee on 06.06. 2014 (approval no. 121). An informed consent was obtained from each study participant. All tests were conducted by a single research team. The researcher who performed the balance analysis was blinded to the prosthesis type placed. All tests were repeated three times at least.

We used a Biodex Balance System (BBS; Biodex Medical Systems Inc., Shirley, NY, USA) to functionally evaluate the balance and fall risk. The BBS consists of a movable balance platform affording up to $20^{\circ}$ of surface tilt over a $360^{\circ}$ range of motion; the platform is interfaced using a computer software (Upper Display Module-Firmware version 1.09; Lower Control BoardFirmware version 1.03, Biodex Medical Systems) which allows the device to objectively assess the postural balance and fall risk. Assessment of postural stability includes derivation of overall osteoarthritis, anteriorposterior (AP), and medial-lateral (ML) stability indices. The results of fall risk tests yield an overall fall risk index (FRI). Higher scores indicate poorer balance and an increased fall risk.
Each subject stood on the BBS platform without footwear with open eyes, the feet shoulder-width apart over the midline of the board, looking straight ahead. Foot positions were recorded and held constant throughout test sessions.

The patients $(n=231)$ who underwent TKA operations between March 2010 and April 2014 were screened. All patients were trained for approximately one minute on the BBS to reduce the incidence of learning effects. All patients underwent three trials (20 s in each) of the postural stability (static level; thus dynamic level 8-6) and fall risk (dynamic level 8-6) tests with a $10 \mathrm{~s}$ rest between each session. The mean scores were automatically calculated from the three sets of test data and reports were prepared by the BBS.

It was identified whether poor balance and fall risk were associated with conditions which preceded or caused by a fall. As a result, the patients with systemic diseases which might affect the balance and fall risk, and those who were taking drugs to treat such conditions were excluded $(n=42)$ (Figure 1).

The remaining 122 patients were tried to reach by phone. However, only 81 responded. Excluding those who refused to participate $(n=40)$, we finally enrolled 41 fully cooperative patients.

During balance evaluation to standardize testing, 41 participants were divided into two groups: a PCLsubstitution group (group 1, $\mathrm{n}=20$ ) in which a single
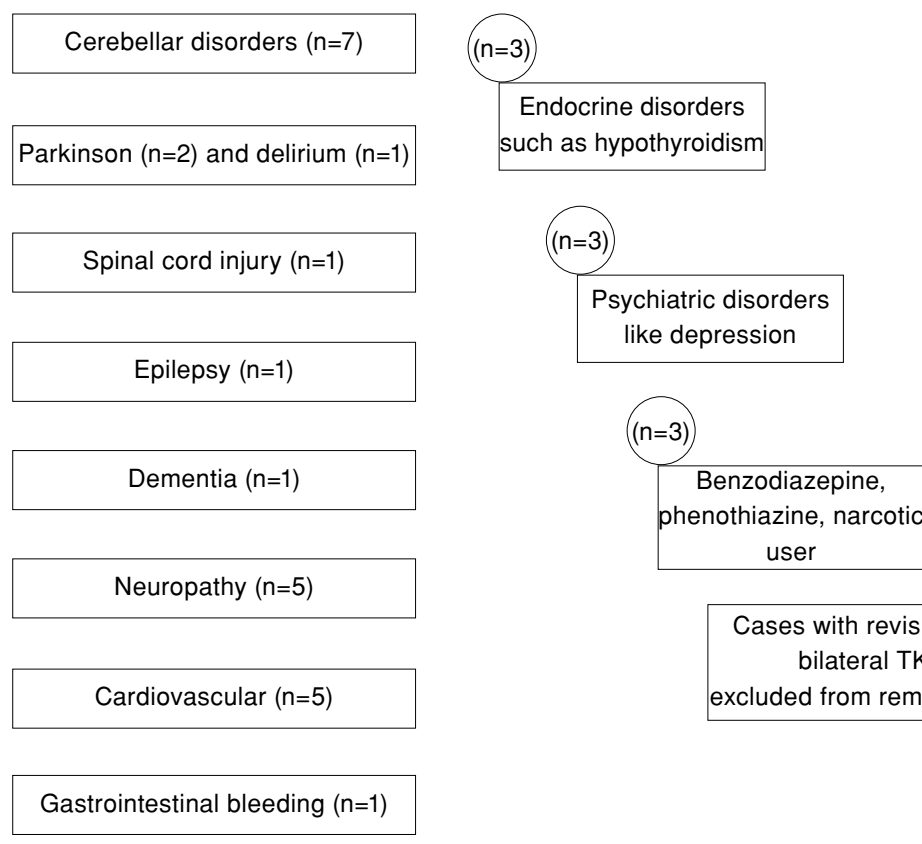

Cases with revision TKA $(n=20)$, bilateral TKA $(n=47)$, excluded from remaining 189 cases.

Figure 1. Exclusion criteria.

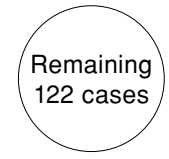


type of ligament-sacrificing mobile insert implant was used, and a PCL-retaining group (group 2, n=21), in which a single type of ligament-retaining fixed insert implant was employed. All operations were performed by a single surgeon.

\section{Clinical evaluation and carried out analysis}

Physical examination was performed. Demographic data including age, sex, and body mass index (BMI) were recorded. ${ }^{[7]}$ The range of motion (ROM) of the joints was assessed. A visual analog scale (VAS) and the Western Ontario and McMaster Universities Arthritis Index (WOMAC) were used to estimate pain and functional disability, respectively. The balance and fall risk assessments were conducted using the Berg Functional Balance Scale (BFBS).

All subjects were evaluated in a balance laboratory using the BBS to derive static and dynamic postural overall stability indices (OSI), the anteroposterior stability index (APSI), the mediolateral stability index (MLSI), and the fall risk index (FRI).

Statistical analysis was performed using SPSS for Windows version 16.0 software (SPSS Inc., Chicago, IL, USA). The data were expressed in mean \pm standard deviation. Prior to analysis, data were subdivided into categorical and continuous data. Categorical data were analyzed using a non-parametric independent t test.

As the sample size was small, the median values were compared using the non-parametric MannWhitney $U$ test and the Wilcoxon signed-rank test. A $p$ value of $<0.05$ was considered statistically significant.

\section{RESULTS}

The percentage of females in group 1 was $80.95 \%$. The mean ages of females and males were 72.0 \pm 7.7 and $65.3 \pm 6.7$ years, respectively. The mean BMI value of females was $34.1 \pm 5.0 \mathrm{~kg} / \mathrm{m}^{2}$ (class 2 obese), while the mean BMI value of males was $33.8 \pm 4.1 \mathrm{~kg} / \mathrm{m}^{2}$ (class 1 obese).

The percentage of males in group 2 was $5 \%$. The mean ages of males and females were $68.4 \pm 6.4$ and $61.0 \pm 00.0$ years, respectively. The male and female BMI values were $35.9 \pm 4.3$ (class 2 obese) and $47.5 \pm 0.0$ (class 3 obese) $\mathrm{kg} / \mathrm{m}^{2}$, respectively. The mean postoperative follow-up for both groups was 25.6 \pm 9.7 months. The mean follow-up for group 1 and group 2 were $26.2 \pm 11.3$ and $24.9 \pm 8.1$ months, respectively.

After initial physical examination, radiographs were obtained and PCL-retaining and PCLsubstitution implants were evaluated. None of the patients had pathological findings after an implant insertion.

In intergroup comparison, there was no significant difference in either VAS or WOMAC scores, reflecting clinical pain and disability, or on the BERG scale measuring balance control and fall risk between the study groups (Table I).

There was no significant difference in experimental postural stability test results (the static OSI, APSI, and MLSI) between the groups. The PCLsubstitution prosthesis (Biomed PCL-Substitution Mobile Insert Prosthesis) of group 1 was superior in terms of balance and postural stability on AP dynamic testing, indicating a significant difference between the groups. The FRI scores were slightly better in the PCL-substitution group; however, the difference did not reach statistical significance (Table II).

\section{DISCUSSION}

Balance problems which impair walking are critical risk factors for falling. ${ }^{[8]}$ Visual, vestibular, and proprioceptive systems, muscle strength, and joint flexibility mechanisms are impaired in $13 \%$ of individuals aged 65-69 years. ${ }^{[9]}$ Similarly, in our study, all patients were aged between 54 and 83 years.

TABLE I

Comparisons of clinical outcomes between two groups

\begin{tabular}{|c|c|c|c|c|c|}
\hline & \multicolumn{2}{|c|}{ Group 1} & \multicolumn{2}{|c|}{ Group 2} & \multirow[b]{3}{*}{$p^{*}$} \\
\hline & Female & Male & Female & Male & \\
\hline & Mean $\pm S D$ & Mean $\pm S D$ & Mean \pm SD & Mean $\pm S D$ & \\
\hline Visual analog scale & $1.61 \pm 1.69$ & $2.00 \pm 2.65$ & $2.47 \pm 2.65$ & $1.0 \pm 0.0$ & 0.11 \\
\hline WOMAC & $62.78 \pm 5.57$ & $69.33 \pm 6.11$ & $63.32 \pm 4.62$ & $66.00 \pm 0.00$ & 0.84 \\
\hline Range of motion & $127 \pm 7.67$ & $126.7 \pm 11.55$ & $121.00 \pm 9.55$ & $110.00 \pm 0.00$ & 0.71 \\
\hline Berg Functional Balance Scale & $45.06 \pm 7.23$ & $48.67 \pm 7.09$ & $46.79 \pm 6.87$ & $50.00 \pm 0.00$ & 0.91 \\
\hline
\end{tabular}

SD: Standard deviation; * $p<0.05$; WOMAC: Western Ontario and McMaster Universities Arthritis Index. 
TABLE II

Evaluation of Biodex balance system data regarding the balance and fall risk

\begin{tabular}{lccccccccc}
\hline Groups & \multicolumn{7}{c}{ Mean rank } \\
\cline { 2 - 9 } & OSI-static & OSI-6 & OSI-8 & APSI-6 & APSI-8 & MLSI-6 & MLSI-8 & FRI-6 & FRI-8 \\
\hline Group 1 $(\mathrm{n}=20)$ & 19.70 & 17.30 & 17.20 & 16.62 & 16.15 & 20.23 & 20.35 & 19.30 & 18.82 \\
Group 2 $(\mathrm{n}=21)$ & 22.24 & 23.70 & 23.80 & 24.38 & 24.85 & 20.65 & 21.71 & 21.70 & 22.18 \\
& & \multicolumn{7}{c}{ Sum of ranks } \\
Group 1 & 394.00 & 346.00 & 344.00 & 332.5 & 323.00 & 405.00 & 407.00 & 386.00 & 376.50 \\
Group 2 & 467.00 & 474.00 & 476.00 & 487.50 & 487.50 & 413.00 & 456.00 & 434.00 & 443.50 \\
U & 184 & 136 & 134 & 122.5 & 113 & 197 & 192 & 176 & 198 \\
$p^{*}$ & 0.496 & 0.086 & 0.076 & 0.035 & 0.018 & 0.947 & 0.841 & 0.529 & 0.369
\end{tabular}

OSI: Overall stability indices; APSI: Anteroposterior stability index; MLSI: Mediolateral stability index; FRI: Fall risk index.

In addition, balance and functional mobility are suggested to be closely related. ${ }^{[10]}$ With advancing age, visual problems, hearing loss, vertigo, the need for supporting devices, comorbidities and polypharmacy may cause balance problems. ${ }^{[1]}$ Prior surgery and the implants used also may increase the risk of falling. Since laboratory methods are not appropriate for the population-based screening of balance, clinical evaluation is required. ${ }^{[12]}$ Moreover, the osteoarthritis index is one of the best indicators of balance. More importantly, some authors have suggested that certain diseases and systemic conditions are associated with an increased risk of falls. ${ }^{[13-15]}$

In the present study, we evaluated balance and fall risk among patients with osteoarthritis, which is a complex condition mechanically, biologically, biomechanically, not only in the laboratory, but also through clinical testing. ${ }^{[16-18]}$ We excluded patients with conditions which negatively affected balance.

Adam et al. ${ }^{[6]}$ compared various PCL-substitution implants in terms of the American Knee Society scores over 24 months. Kim et al. ${ }^{[19]}$ presented 68 monthfollow-up data. In the present study, we compared balance and fall risks for 25.6 \pm 9.7 months.

Furthermore, PCL delivers $85-100 \%$ of the force, thereby, preventing posterior tibial translation. ${ }^{[20]} \mathrm{As}$ in our study population who underwent TKA, we evaluated the BBS in the coronal plane, supported by medial and lateral collateral ligaments. We also analyzed BBS in the sagittal plane, supported by the anterior cruciate ligament and the PCL. We found no significant differences in MLSI static or dynamic values between the groups. However, the PCLsubstitution group had improved balance, reflected by the APSI dynamic scores in the sagittal plane (APSI-6: $\mathrm{U}=122.5, \mathrm{p}=0.035$; APSI-8: $\mathrm{U}=113, \mathrm{p}=0.018$ ).
We believe that the significant differences between PCL-retaining and PCL-substitution prostheses indicate an importance, as although balance was significantly affected in the sagittal plane, but not in the coronal plane. Thus, how much of the PCL is preserved upon use of a PCLretaining prosthesis? Sessa et al. ${ }^{[21]}$ showed that the PCL was injured during the tibial cut. Feyen et al. ${ }^{[2]}$ found similar results in a cadaver study. Some in vivo fluoroscopic explorations have shown that the reduction in femoral rollback is higher when a PCLretaining prosthesis, rather than a PCL-substitution prosthesis, is placed. ${ }^{[23]}$ Both the femoral and tibial components of a PCL-substitution prosthesis seek to replace the PCL. However, in a PCL-retaining prosthesis, both femoral rollback and coronal stability are afforded by the PCL per se.

Furthermore, the APSI- 6 and APSI- 8 dynamic tests showed that patients with PCL-retaining prostheses were at an increased risk for falling.

There is a limitation to our study. Although we excluded patients with risk factors for falls and poor balance, we were unable to exclude those with a high BMI value, which may negatively affect postural dynamic balance. The mean BMI values of both males and females were $41.7 \pm 4.1 \mathrm{~kg} / \mathrm{m}^{2}$. Therefore, it is not clear whether the imbalance was caused by a high BMI value or a feature of the prosthesis. In addition, we were unable to present in vivo or in vitro animal data.

In addition, there is no data on preoperative balance and fall risk Although it seems a limitation, factors which affect the balance and fall risk were regarded as exclusion criteria. Therefore, these patients were excluded and remaining patients were considered eligible preoperatively for the balance and fall risk. 


\section{Conclusion}

We concluded that PCL substitution prosthesis design should be considered in the operations of the patients who have risk factors for balance disorder and an increased fall risk, such as visual impairment, dementia, epilepsy, cerebellar disorders. Therefore, we can reduce possible risk factors for balance disorder and fall risk.

\section{Acknowledgments}

We are thankful to Pharmacologist \& Pharmacist Ibrahim Yilmaz of the Pharmacovigilance and Rational Drug Use Committee of the Turkish Ministry of Health for determining the exclusion criteria and edited the article and made suggested revisions for grammar, word choice, wordiness, awkward phrases, clarity, etc. and for aiding in statistical evaluation of BBS data as an independent individual.

\section{Declaration of conflicting interests}

The authors declared no conflicts of interest with respect to the authorship and/or publication of this article.

\section{Funding}

The authors received no financial support for the research and/or authorship of this article.

\section{REFERENCES}

1. Alexander BH, Rivara FP, Wolf ME. The cost and frequency of hospitalization for fall-related injuries in older adults. Am J Public Health 1992;82:1020-3.

2. Moppett IK, Greenhaff PL, Ollivere BJ, Joachim T, Lobo DN, Rowlands M. Pre-Operative nutrition In Neck of femur Trial (POINT)--carbohydrate loading in patients with fragility hip fracture: study protocol for a randomised controlled trial. Trials 2014;15:475.

3. Barbour KE, Stevens JA, Helmick CG, Luo YH, Murphy LB, Hootman JM, et al. Falls and fall injuries among adults with arthritis--United States, 2012. MMWR Morb Mortal Wkly Rep 2014;63:379-83.

4. Lamb SE, Jørstad-Stein EC, Hauer K, Becker C. Development of a common outcome data set for fall injury prevention trials: the Prevention of Falls Network Europe consensus. J Am Geriatr Soc 2005;53:1618-22.

5. Nevitt MC, Cummings SR, Hudes ES. Risk factors for injurious falls: a prospective study. J Gerontol 1991;46:164-70.

6. Adam R, Orban C, Orban H. Comparative study of design and PCL-substituting systems of total knee prosthesis. Chirurgia (Bucur) 2014;109:99-103.

7. Bakırhan S, Unver B, Karatosun V. Investigation of body weight ratios on joint structures at different knee flexion angles in patients with unilateral knee arthroplasty. [Article in Turkish] Eklem Hastalik Cerrahisi 2013;24:7-11.
8. Bueno-Cavanillas A, Padilla-Ruiz F, Jiménez-Moleón JJ, Peinado-Alonso CA, Gálvez-Vargas R. Risk factors in falls among the elderly according to extrinsic and intrinsic precipitating causes. Eur J Epidemiol 2000;16:849-59.

9. Felsenthal G, Ference TS, Young MA. Aging of organ systems In: Gonzales EG, Myers SA, Edelstein JE, Lieberman JS, Downey JA, editors. Downey and Darling's Physiological Basis of Rehabilitation Medicine. 3rd ed. Boston: Butterwoth Heinemann; 2001. p. 561-77.

10. Hatch J, Gill-Body KM, Portney LG. Determinants of balance confidence in community-dwelling elderly people. Phys Ther 2003;83:1072-9.

11. Tinetti ME, McAvay G, Claus E. Does multiple risk factor reduction explain the reduction in fall rate in the Yale FICSIT Trial? Frailty and Injuries Cooperative Studies of Intervention Techniques. Am J Epidemiol 1996;144:389-99.

12. Mathias S, Nayak US, Isaacs B. Balance in elderly patients: the "get-up and go" test. Balance in elderly patients: the "get-up and go" test. Arch Phys Med Rehabil 1986;67:387-9.

13. Testerman C, Vander Griend R. Evaluation of ankle instability using the Biodex Stability System. Foot Ankle Int 1999;20:317-21.

14. Lipsitz LA, Jonsson PV, Kelley MM, Koestner JS. Causes and correlates of recurrent falls in ambulatory frail elderly. J Gerontol 1991;46:114-22.

15. Salgado R, Lord SR, Packer J, Ehrlich F. Factors associated with falling in elderly hospital patients. Gerontology 1994;40:325-31.

16. Atik OŞ. The role of metabolomics in osteoarthritis for early diagnosis, monitoring prognosis and treatment. Eklem Hastalik Cerrahisi 2015;26:1.

17. Bakirhan S, Angin S, Karatosun V, Unver B, Günal I. A comparison of static and dynamic balance in patients with unilateral and bilateral total knee arthroplasty. Eklem Hastalik Cerrahisi 2009;20:93-101.

18. Bek D, Ege T, Yıldız C, Tunay S, Başbozkurt M. The accuracy of two different extra-medullary tibial cutting guides for posterior tibial slope in total knee arthroplasty. Eklem Hastalik Cerrahisi 2014;25:75-9.

19. Kim KT, Kang MS, Lim YH, Park JW, Wang L. Short-Term Results of Total Knee Arthroplasty with Anterior-Posterior Glide LCS Mobile-Bearing System. Knee Surg Relat Res 2014;26:162-7.

20. Cury Rde P, Mestriner MB, Kaleka CC, Severino NR, de Oliveira VM, Camargo OP. Double-bundle PCL reconstruction using autogenous quadriceps tendon and semitendinous graft: surgical technique with 2-year followup clinical results. Knee 2014;21:763-8.

21. Sessa P, Fioravanti G, Giannicola G, Cinotti G. The risk of sacrificing the PCL in cruciate retaining total knee arthroplasty and the relationship to the sagittal inclination of the tibial plateau. Knee 2015;22:51-5.

22. Feyen H, Van Opstal N, Bellemans J. Partial resection of the PCL insertion site during tibial preparation in cruciateretaining TKA. Knee Surg Sports Traumatol Arthrosc 2013;21:2674-9.

23. Dennis DA, Komistek RD, Mahfouz MR, Haas BD, Stiehl JB. Multicenter determination of in vivo kinematics after total knee arthroplasty. Clin Orthop Relat Res 2003;416:37-57. 